\title{
Practice and Exploration in the Construction of the Demonstration Training Base for Business Administration
}

\author{
Shujuan Yu
}

Department of Economics and Management, Zhejiang University of Water Resource and Electric Power, Hangzhou 310018, China

Keywords: Business administration; demonstration training base; practical teaching; higher education

\begin{abstract}
Practical teaching is a significant part of higher education talents cultivation, which serves as the vital link for students to master their theoretical knowledge and basic skills. The improvement of practical teaching is relied on the construction of internal and external training facilities. We summarize the experience and exploration of the construction of the business management training base at the Zhejiang Institute of Water Conservancy and Hydropower. It expounds the teaching ideas in business simulation and on-the-job training based on real business environment. Through the dynamic combination of theory and practice in teaching, the university establishes a "progressive and multi-level practical teaching system" characterized by multi-level and multi-module pattern, relative independence and interconnection, so as to cater for the training facilities and the environment. Using of practical training facilities to carry out school-enterprise cooperation, introducing enterprises into the campus, introducing business into classroom, solving the needs of students practical skills effectively, special training and comprehensive training, and achieve the effect of improving students' ability to adapt to work.
\end{abstract}

\section{Introduction}

Practical teaching is a significant part of higher education personnel training. Practical and theoretical teaching are closely connected but relatively independent from one another, which serves as the vital link for students to master their theoretical knowledge and basic skills[1]. Business Administration has a strong applicability. However, considering business confidentiality, enterprises are reluctant to offer internship to students because they lack familiarity with business owing to the short internship period. Some enterprises are willing to offer admission to students while the work is solely focused on shortterm marketing or customer service. In this case, students can not reach the core content of business[2]. Therefore, the professional practice becomes a difficult problem that must be faced. On one hand, it is necessary for the higher college talents to obtain skill training for knowledge transformation. On the other hand, the training satisfies students' needs for obtaining the adaptability to work. Combining several years' training and teaching experience and the construction of Demonstration Training Base for Business Administration, the university has explored and set up many majors such as Business Administration, Logistics, Marketing, and E-commerce. Through the dynamic combination with theoretical teaching, it has established a "progressive and multi-level practical teaching system" characterized by multi-level and multi-module pattern, relative independence and interconnection. By providing training programs for students in different majors, it is ensured that the experimental teaching will become a significant link for students to cultivate their practical ability.

\section{Ideas on Demonstration Base Construction and Practical Teaching Platform Positioning}

In terms of training base construction, practical teaching must be treated as the top priority. Practical teaching and knowledge output are two of the fundamental functions that on-campus training base of economic management majors must be required. The university has built real business environment and created simulation business practice, which can truly address the imbalance between management knowledge and skill practice, and help students strengthen their practical ability. The training base construction of business enterprise should mirror the progressive process from verification to cognition, from one program to integration, from internality to externality, and from application to innovation. 
The university aims to build an on-campus training base characterized by the mode that features in the integration of simulated and real business environment and operation[3]. This covers profession teaching, post skill, or vocational training. From the essence in professional quality to specialized and comprehensive skills, the profession-oriented idea has also been integrated in the impartment of knowledge, skill training and professional quality. The philosophy of coordination between practical and theoretical teaching, the combination of personal skills and team spirit, and the mutual progress in study[4], practice and innovation, has made overall plans for each major's basic training resources to optimize the original allocation, fulfilled the target of sharing resources and brought enterprises into campus. All these enable the university to possess the function that highlights business simulation, real operation and professional skill training. These could satisfy students' needs of specialized training in "post skill” and the comprehensive practice in "quality cultivation".

\section{The Framework Design of the Demonstration Training Base}

The on-campus training base functioning as a carrier that combines both enterprises and universities is the practical and teaching direction and requirement for the economic management majors. The biggest advantage of the base is that students can have opportunity to experience the real business environment, tasks, enterprises' management as well as the market assessment standard. Therefore, the base can satisfy the fundamental requirements of practical skill training and professional quality cultivation.

\subsection{Improvements on the simulation training facilities}

The training base has sorted out the original facilities and software in accordance with skills. It developed basic and public training programs, and upgraded some of the software[4], such as Enterprise Management Simulation, Accounting Computerization, International Trade Practice, etc. It has made a purchase of targeted software for national college management major contests, such as: Simulation of Enterprise Competition, Human Resources Sand Table, International Trade and Business, Logistics planning, etc. It has also made a purchase of the equipment for practical training, such as engraving plotter, forklift, and attendance machine. Combining the major construction and the development, the university has built a psychological laboratory, a behavioral observation room, and a business negotiation room as well, so as to improve the existing training condition.

\subsection{Increase in the number of practical training facilities}

Cooperating with enterprises to build new production and processing center, the training base will be exposed in the enterprise-oriented environment, and it has established the training center with production and operation capacity; these measures can help solve the problem in a majority of students' needs for internship, therefore, students are given the practical opportunity through the post-practice.

The university works closely, with enterprises and the method "bring enterprise into classroom" means introducing the real business operation into teaching activities, involving students with real business environment by engaging them with real programs. As the "employee-to-be", students can not only join the enterprise's activities, but also carry out business rotation of various management positions. Strengthening the abilities, such as exploring spirit, scientific mind, practice and innovation, can meet the "three-sphere" requirements in technique, quality, employment and entrepreneurship training, which students must acquire, and provide them with training in the whole process of "learning-practicing and skill-using”. The specific measures include bringing into university the short-term or long-term university-enterprise cooperation with foreign trade enterprises, third-party logistics enterprises (TPL), telemarketing, and e-commerce companies. For examples, in short-term practical training programs, students can engage in e-commerce customer service and sales, and process the business of tally, delivery and order during annual "Double Eleven” festival. Long-term practical training programs include sales and management training. That is, bringing a telemarketing company to carry out telemarketing practice with precision marketing lab. Meanwhile, students can participate in management under the joint guidance of business staff and teachers, which can dynamically combine the marketing, business enterprise training base, and comprehensive graduate practice. 


\section{Achievements}

\subsection{Promotion in diversified talents cultivation}

The real operation and production system can improve teaching better, shorten the disconnection between teaching and reality[6], help students know about job responsibility, and enhance their professional quality and management skills. Enterprise staff, including technicians and salesmen, can give guidance, check and supervision to students. In turn, students join in the business such as production, product installment and sales. Among the above activities, students can accumulate market-docking practical training experience. The training base chooses telemarketing for integrated teaching in terms of learning, operating and practicing. By bringing enterprise into university and operating real projects, the university endeavors to explore the teaching mode based on university-enterprise cooperation and alternation between work and study.

Creating work environment characterized by "Simulation plus Real Business" and "Simulation plus Real Work”, which can improve students' professional ability. Under the existing simulation business environment, university can build an electronic product processing and assembly center and a marketing room through university-enterprise cooperation, so as to satisfy students' needs in training for "post skill" and "quality cultivation". Enterprise staff can enter university and operate business in accordance with the enterprise mode. Therefore, the task-based teaching and practice mode can be achieved, and it helps students turn their role into employees. Meanwhile, it can provide guidance and training for student's business start-up and career choice.

\subsection{Promotion in professional construction and curriculum reform}

In response to the requirements of training base construction, the talent training program for each major has been adjusted and modified accordingly. Practical training program includes more in-class experiments, comprehensive simulation practice, and enterprise business, it hires the enterprise staff to undertake the teaching tasks with strong practicability[5,6], such as declaration practice, management of small and medium-sized enterprises, entrepreneurship science and so on. These make teaching content more practical. The practical training of enterprises inside and outside the university has changed the single examination mode, constructed a multi-examination system composed of teachers, students and enterprises and increased the weight of enterprise evaluation. The introduction of the third-party evaluation not only enhances the supervision and examination of practical teaching, but also strengthens the guidance of the enterprise staff practical teaching. Therefore, it can achieve the goal of university-enterprise cooperation on education, and fully embody the function and significance of practical project management and evaluation.

\subsection{Improvement of the practical curriculum system}

The practical curriculum system is divided into three parts, professional basic ability training, post core skills training and post comprehensive post training. These types of practical training can not only strengthen students' professional, basic and comprehensive skills, but also deepen students' understanding of the position in the comprehensive way. Taking business administration major as an example, the practical training system is characterized by progressive and multi-level practical teaching system, which covers "point-line-plane" pattern in the aspects of skill, position and profession, and is constructed according to the enterprise management position like production management, sales management, human resource management, financial management and logistics management. Meanwhile, the cultivation of students' entrepreneurship and innovation ability should also be taken into consideration. The system is designed in accordance with the process like "Corporate Cognition-Specific Training-Comprehensive Practice-Employment Practice". It starts from the analysis of business administration position, and extracts the elements of core vocational ability, specific and comprehensive ability that the targeted position has required. It will also confirm the requirements of talents training about knowledge, ability and quality based on these capability elements. Hereby, the practical course system such as training and practice is designed. It has both the in-class simulation experiment and the practice of sculpture production and network marketing, so as to improve students' ability of post use and postpractice. 


\subsection{Raising the quality of teachers}

Through university-enterprise cooperation, some enterprises are brought into the university. A simulation training center and a telemarketing training center will be created in order to build a real production and operation training center that can connect with the market. It can also drive teachers to participate in practical projects. After a period of cooperation, the university and the enterprise have coestablished a practical course-oriented training system and jointly developed practical training courses for key positions in terms of core competence. A professional team of teachers' structures and qualities of "dual-teacher" are also built to improve the training and coaching ability for teachers

\subsection{By taking the training base as the platform to organize colorful second classroom activities, the university can cultivate students' entrepreneurial and innovative abilities.}

The training base will continue to organize discipline competitions and take advantage of online entrepreneurship platforms to allow more students to carry out self-employment activities and create and enrich the cultural atmosphere of science and technology on campus. At the same time, the training base will expand the comprehensive knowledge for college students in various aspects and ways, and cultivate college students' awareness of independent innovation, creative thinking, practical ability and team-work spirit.

The base will be open to the students regularly to hold the competition of enterprise management simulation with sand table and the contest of enterprise management or decision-making simulation. The non-metal crafts sculpture competition, forklift skills competition, business skills competition will be held for the economics and management students. They will be encouraged to start a business online. The construction of the demonstration base has changed the practical teaching of our university's students whose major are management. Originally, they could only conduct case analysis, software simulation operations, or demonstrations, but now simulations and practical projects have been added. These measures effectively enhance students' professional skills and increase practical experience.

\section{Conclusion}

Practical teaching is an important part in universities and colleges. It is an indispensable link for improving teaching quality and the cultivation of innovative talents[7]. The improvement of practical teaching is relied on the construction of internal and external training facilities, so as to solve many existing problems in the practical training of management majors. This paper combines the construction of the demonstration training base for business management in our university and summarizes the achievements of the training base construction and practical teaching. It is hoped that our research and practice will serve as a reference for deepening the practical teaching reform of economics and management majors.

\section{References}

[1]. Zaihua Wu, Mudan Yang. Literature review on practical teaching of business administration major. Theory and Practical of Contemporary Education. 2016(3):57-60

[2]. Hua Xie, Changmao Jiang. Research of the Practical Teaching System Construction Based on "Market Orientation-Work-Integrated Learning": Taking Property Management Major for Example. Value Engineering.2013(15):261-226

[3]. ZhuQing Zhang. Study on the management and exploration in the construction of the demonstration training base for Business Administration--taking Liaoning Technical Institute of Economics as an example. Journal of Liaoning Economic Vocational Technological Institute.2017(5):111-113

[4]. Jian Lao. The Research and Practice of the Long-term Operational Mechanism of the Productionoriented Practical Training Base for University and Enterprises Co-building in Logistics major of Higher Vocational. Rural Economy and Science-Technology. 2016, 27 (10):214-214 
[5]. Yujun Yin. Exploration on Long-term Mechanism of Productive Training Base in Higher Vocational Colleges. Journal of Electrical \& Electronic Education , 2017,39 (3):141-143

[6]. Fei Wu.Reflections on the Construction of internship base for management major in business school. 2015 Beijing Undergraduate Teaching Work Conference.2015(10)

[7]. Yujuan Sun, Jinzeng Wang, Tian Tian. Promotion and reform of Practical Teaching Models of Management. Journal of Tangshan Teachers College.2012 (1): 158-160 